\begin{tabular}{|c|c|c|}
\hline B! & $\begin{array}{l}\text { BIODIK: Jurnal IImiah Pendidikan Biologi } \\
\text { ISSN 2580-0922 (online), ISSN 2460-2612 (print) } \\
\text { Volume 07, Nomor 04, Tahun 2021, Hal. 39-49 } \\
\text { Available online at: } \\
\text { https://online-journal.unja.ac.id/biodik }\end{array}$ & BIODIK \\
\hline
\end{tabular}

Research Article

\title{
Efektivitas Blended Learning Berbasis Quided Inquiry Terhadap Penguasaan Konsep Dan Kemampuan Berpikir Kreatif Mahasiswa Pada Mata Kuliah Anatomi Fisiologi Manusia
}

\author{
(The Effectiveness of Blended Learning Based Quided inquiry on The Mastery of Concepts and \\ The Ability of Creative Thinking of Students in a Course Anatomy Human Physiology)
}

\author{
Rahmawida Putri*, Nuriyatul Fhatonah \\ Program Studi Farmasi, Sekolah Tinggi Farmasi Muhammadiyah Tangerang \\ JI. KH. Syekh Nawawi KM 4 No. 13 Matagara, Tigaraksa, Kabupaten Tangerang, Banten \\ ${ }^{*}$ Corresponding Autors : rahmawidaputri0@gmail.com
}

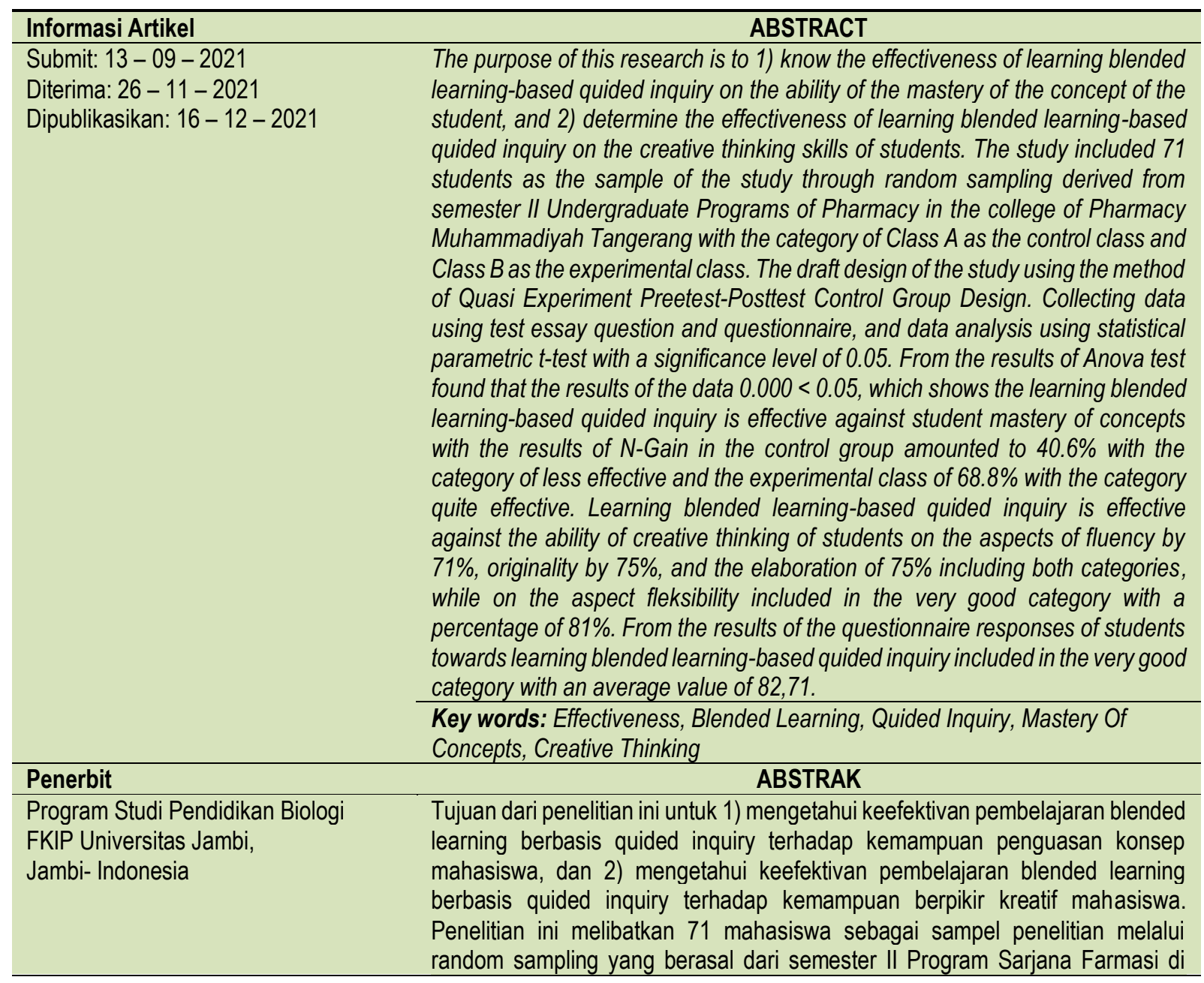


Sekolah Tinggi Farmasi Muhammadiyah Tangerang dengan kategori Kelas A sebagai kelas kontrol dan Kelas B sebagai kelas eksperimen. Rancangan desain penelitian menggunakan metode Quasi Experiment Preetest-Posttest Control Group Design. Pengumpulan data menggunakan tes soal essay dan angket, dan analisis data menggunakan statistik parametrik uji-t dengan taraf signifikansi 0,05 . Dari hasil uji Anova diperoleh bahwa hasil data $0,000<0,05$ yang menunjukkan pembelajaran blended learning berbasis quided inquiry efektif terhadap penguasaan konsep mahasiswa dengan hasil N-Gain pada kelompok kontrol sebesar 40,6\% dengan kategori kurang efektif dan kelas eksperimen sebesar $68,8 \%$ dengan kategori cukup efektif. Pembelajaran blended learning berbasis quided inquiry efektif terhadap kemampuan berpikir kreatif mahasiswa pada aspek fluency sebesar $71 \%$, originality sebesar $75 \%$, dan elaboration sebesar $75 \%$ termasuk kategori baik, sedangkan pada aspek fleksibility termasuk ke dalam kategori sangat baik dengan persentase $81 \%$. Dari hasil angket tanggapan mahasiswa terhadap pembelajaran blended learning berbasis quided inquiry termasuk dalam kategori sangat baik dengan nilai rata-rata 82,71. Kata kunci: Efektivitas, Blended Learning, Quided Inquiry, Penguasaan Konsep, Berpikir Kreatif

\section{PENDAHULUAN}

Perkembangan kemajuan teknologi informasi membawa perubahan dalam dunia pendidikan. Perubahan tersebut menuntut peserta didik untuk memiliki kemampuan memahami konsep dan memiliki kemampuan berpikir kreatif, pengetahuan dan kemampuan literasi digital, literasi informasi, dan literasi media serta menguasai teknologi dan komunikasi (Frydenberg \& Andone, 2011; 314). Pembelajaran pada abad 21 menuntut mahasiswa tidak berperan sebagai obyek pembelajaran dan menerima semua informasi hanya dari dosen, melainkan sebagai pelaku utama dalam pembelajaran dan dosen merupakan fasilisator dalam pembelajaran. Salah satu yang dapat dilakukan yaitu menerapkan penggunaan internet dalam pembelajaran dimana menurut Trilling \& Fadel $(2009 ; 50)$ dan Wardani, dkk (2018; 14) bahwa penggunaan internet dalam pembelajaran mampu mengembangkan kemampuan mahasiswa dalam keterampilan teknologi dan media informasi serta proses pembelajaran dapat berlangsung.

Pembelajaran abad 21 menentukan pencapaian mahasiswa salah satunya melalui penggunaan pendekatan model pembelajaran. Model pembelajaran dapat diterapkan dengan menggunakan teknologi informasi dengan menerapkan model Student Centered Learning yang menempatkan mahasiswa sebagai pusat pembelajaran dan diharapkan aktif serta mandiri dalam proses pembelajaran. Penerapan model ini diharapkan mahasiswa dapat bertanggungjawab dengan menemukan sumber informasi dalam mengatasi masalah dengan dosen bertugas sebagai fasilisator dalam proses pembelajaran.

Menurut Husni, dkk (2010; 452) dan Ulfa \& Husnannisa (2021; 415) bahwa pemanfaatan komputer dalam proses pembelajaran dapat meningkatkan kemampuan pemahaman konsep dan berpikir kreatif serta meningkatkan kemampuan mencari informasi. Penerapan komputer berbasis web dengan memanfaatkan berbagai aplikasi online melalui media internet dapat membantu memperbaiki miskonsepsi peserta didik, membantu meningkatkan kemandirian dan pemberian tanggapan (Bawaneh, 2011;45 dan Indrawan, dkk, 2019:71)

Program studi Farmasi Sekolah Tinggi Farmasi Muhammadiyah Tangerang memiliki tujuan menghasilkan lulusan terdidik, terampil, dan terlatih dalam dunia kerja yang relevan dengan 
perkembangan dunia pendidikan. Pada mata kuliah Anatomi Fisiologi Manusia mahasiswa ditekankan harus mengembangkan rasa ingin tahu melalui penemuan/inquiry berdasarkan pengalaman langsung yang dilakukan melalui kerja ilmiah untuk memanfaatkan fakta, membangun konsep, prinsip, teori, dan hukum. Pembelajaran pada abad 21 dapat dilakukan tanpa melalui tatap muka secara langsung dengan memanfaatkan teknologi informasi sehingga dapat meningkatkan kemampuan kemandirian mahasiswa, menguji diri secara online, serta dapat menerima pembelajaran melalui pengalaman melalui Virtual Reality Radiotherapy (VERT) (Wardani, dkk, 2018; 15 dan Czaplinski \& Fielding, 2020:23).

Ketrampilan berpikir kreatif harus selalu menghasilkan ide, pendapat, maupun gagasan baru untuk mencapai suatu tujuan yang diharapkan. Indikator berpikir kreatif untuk mengembangkan suatu ide kreatif dan inovatif diantaranya, aspek kelancaran (fluency) dengan menciptakan suatu ide dan gagasan dan dapat mengemukakan solusi dengan lancar; aspek kelenturan (flexibility) dengan menghasilkan variasi ide serta gagasan dari berbagai sudut pandang; aspek keaslian (originality) menghasilkan ide dan gagasan baru dengan hal baru; dan aspek penguraian (elaboration) dengan mengembangkan ide maupun gagasan yang menarik dan bermakna (Mayasari, dkk. 2016; 151).

Menurut Winarsih \& Priatmoko $(2019 ; 31)$ bahwa penguasaan konsep merupakan kemampuan seseorang dalam memahami, mengaplikasikan, mengklasifikasikan, menerapkan, mensintesis, serta menyimpulkan suatu objek. Penguasaan konsep pada mahasiswa dapat ditingkatkan melalui peranan pembelajaran berbasis multimedia dengan memanfaatkan aplikasi internet (Fatwa, dkk. 2018; 123)

Kenyataannya masih banyak design pembelajaran yang diterapkan oleh dosen tidak memuat keterampilan pada abad 21. Berdasarkan hasil observasi di Sekolah Tinggi Farmasi Muhammadiyah Tangerang melalui metode wawancara dengan dosen mata kuliah Anatomi Fisiologi Manusia yang diajarkan pada semester 2 (semester genap) tahun ajaran 2019/2020 dan observasi kegiatan belajar mengajar memperlihatkan bahwa ada beberapa kendala dalam pembelajaran yang diterapkan. Kendala pembelajaran dalam mata kuliah Anatomi Fisiologi Manusia yang dialami oleh dosen mata kuliah Anatomi Fisiologi Manusia di Sekolah Tinggi Farmasi Muhammadiyah Tangerang adalah hasil belajar mahasiswa yang kurang maksimal. Salah satunya dikarenakan sistem pembelajaran yang masih menggunakan metode ceramah.

Permasalahan yang terjadi dikarenakan pembelajaran masih bersifat teacher centered. Sehingga harus dilakukan perubahan paradigma pembelajaran menuju students centered. Pembelajaran yang menitikberatkan kegiatan pembelajaran kepada mahasiswa salah satunya adalah blended learning yakni pembelajaran yang mengkombinasikan metode pembelajaran tatap muka dengan metode pembelajaran yang memanfaatkan teknologi informasi berbasis web dengan menggunakan berbagai aplikasi (Istiningsih \& Hasbullah, 2015; 51 dan Rahayu \& Nuryata, 2010; 50).

Pembelajaran blended learning merupakan salah satu metode pembelajaran bauran (penggabungan) antara pembelajaran online dan pembelajaran offline yang mempunyai banyak keunggulan dengan tujuan meningkatkan kinerja mahasiswa, mempermudah pengelolaan kelas, serta mengontrol cara dan tempat atau ruang belajar sesuai dengan kebutuhan (Borba, et all. 2016; 592).

Berdasarkan hasil penelitian bahwa pembelajaran blended learning dapat meningkatkan performa mahasiswa dikarenakan melibatkan keaktifan mahasiswa dan mahasiswa mendapatkan umpan balik. Kemampuan penguasaan konsep dan berpikir kreatif mahasiswa dapat mengalami peningkatan dengan mengkombinasikan pembelajaran blended learning dengan salah satu strategi pembelajaran yakni quided inquiry yang memusatkan pembelajaran pada mahasiswa dengan dosen sebagai fasilisator dalam proses pembelajaran, sehingga mahasiswa memiliki kemampuan kemandirian dan aktif secara 
personaliti serta mampu menyelesaikan masalah yang diberikan (Hermawanto, dkk, 2013;69). Sejalan dengan penelitian Akhmalia, dkk (2018; 62) penguasaan konsep siswa pada kelompok kontrol dengan nilai N-Gain 0,70 yang termasuk kategori sedang sedangkan pada kelompok eksperimen dengan nilai $\mathrm{N}$ Gain 0,84 yang termasuk kategori tinggi menunjukkan bahawa blended learning berbasis LMS dengan model pembelajaran inkuiri efektif terhadap pemahaman konsep siswa. Zinnuraini, dkk (2021; 420) dalam hasil penelitiannya menunjukkan bahwa blended learning berpengaruh terhadap peningkatan kemampuan berpikir kreatif siswa sebesar $92 \%$ dengan estimasi dampak sebesar 0,92 termasuk dalam kategori sangat tinggi. Hal senada dipaparkan oleh Susilowati dan Dewantara (2021:4) bahwa penerapan pembelajaran blended learning efektif meningkatkan kemampuan berpikir kreatif mahasiswa calon guru fisika dengan perhitungan effect size sebesar 0,96 termasuk kategori tinggi. Dalam penelitian Aini dan Ismono (2020:74) bahwa model pembelajaran quided inquiry berbasis blended learning dapat melatih kemampuan berpikir kreatif siswa dengan $n$-gain dengan hasil rata-rata $\geq 0,7$ atau katergori tinggi

Menilik dari permasalahan tersebut, maka peneliti tertarik melakukan suatu penelitian yang terfokus dalam penerapan model pembelajaran blended learning berbasis quided inquiry pada proses pembelajaran sehingga metode pembelajaran dapat bervariasi. Hal ini karena model pembelajaran guided inquiry lebih menekankan pada keaktifan, pemahaman konsep, serta kemampuan berpikir kreatif mahasiswa (Khomaidah, Koeswanti. 2020).

\section{METODE PENELITIAN}

Penelitian ini menggunakan design quasy experiment (eksperimen semu) dengan jenis nonequivalent pretest-posttest control group design. Dari populasi 109 mahasiswa yang terdiri dari 3 kelas dipilih secara random sampling untuk penentuan sampel yang terdiri dari 36 mahasiswa dari kelas $A$ sebagai kelas kontrol dan 35 mahasiswa dari kelas B sebagai kelas eksperimen. Kelas kontrol diberikan perlakuan pembelajaran secara e-learning, sedangkan kelas eksperimen diberikan perlakuan pembelajaran blended learning berbasis quided inquiry (Purwanto, 2013).

Pretest-postest control group design adalah desain penelitian ini terdiri dari dua kelompok yang dipilih secara acak (random), selanjutnya diberi pretest sebelum pembelajaran dan posttest setelah pembelajaran yang berfungsi untuk mengetahui adalah perbedaan antara kelompok kontrol dengan menggunakan pembelajaran e-learning dan kelompok eksperimen dengan menggunakan pembelajaran blended learning berbasis guided inquiry (Sudarmanto, 2021). Desain penelitian dapat dilihat pada gambar dibawah ini.

Tabel 1. Desain Penelitian (Sugiyono, 2010:112)

\begin{tabular}{cccc}
\hline Kelas & Preetest & Perlakuan & Posttest \\
\hline Kontrol & $\mathrm{O}_{1}$ & $\mathrm{X}_{1}$ & $\mathrm{O}_{2}$ \\
\hline Eksperimen & $\mathrm{O}_{3}$ & $\mathrm{X}_{2}$ & $\mathrm{O}_{4}$ \\
\hline
\end{tabular}

Variabel bebas pada penelitian ini adalah blended learning berbasis quided inquiry, sedangkan variabel terikat adalah penguasaan konsep dan kemampuan berpikir kreatif mahasiswa. Instrumen yang digunakan dalam penelitian ini berupa draft wawancara, Rencana Pembelajaran Semester (RPS) dan tes berupa soal essay dimana memuat tiap indikator kognitif siswa yang digunakan saat pretest dan posttest.

Data yang diperoleh pada penelitian ini, yaitu penguasaan konsep mahasiswa pada ranah kognitif. Setelah data diperoleh, maka dilakukan uji analisis data berupa uji N-Gain. Kemudian uji normalitas dengan Kolmogrov-Smirnov yang bertujuan untuk mengetahui data yang diperoleh 
berdistribusi normal atau tidak, dengan pengambilan keputusan jika nilai signifikansi $>0,05$ data terdistribusi normal dan nilai signifikansi $\leq 0,05$ data tidak terdistribusi normal. Selanjutnya uji homogenitas yang bertujuan untuk mengetahui varian dalam populasi tersebut homogen atau tidak, jika signifikansi >0,05 data homogen dan nilai signifikansi $\leq 0,05$ data tidak homogen. Terakhir, yaitu uji analysis of variance (ANOVA) untuk mengetahui apakah hipotesis dapat diterima atau ditolak, dengan pengambilan keputusan jika data $0,000<0,05$ pada nilai preetest dan posttest kelas kontrol dan kelas eksperimen, maka pembelajaran blended learning berbasis quided inquiry berpengaruh terhadap kemampuan pemahaman konsep mahasiswa. Data selanjutnya diperoleh dari nilai aspek keterampilan berpikir kreatif mahasiswa pada kelas eksperimen lebih tinggi dibandingkan dengan kelas kontrol maka pembelajaran blended learning berbasis quided inquiry efektif dalam meningkatkan kemampuan berpikir kreatif mahasiswa. Serta data hasil respon mahasiswa yang diberikan pembelajaran blended learning berbasis quided inquiry.

\section{HASIL PENELITIAN DAN PEMBAHASAN}

\section{Analisis Pemahaman Konsep}

Nilai yang telah didapatkan dilakukan analisis data secara normalitas yang berarti jika hasil data perhitungan > 0,05 maka data yang diperoleh dinyatakan berdistribusi normal.

Tabel 1. Hasil Uji Normalitas Kemampuan Kelompok Kontrol (E-Learning)

\begin{tabular}{cccccccc}
\hline \multicolumn{2}{c}{ Kelas } & \multicolumn{3}{c}{ Kolmogorov-Smirnov } & \multicolumn{3}{c}{ Shapiro-Wilk } \\
\cline { 2 - 7 } & Statistic & df & Sig. & Statistic & df & Sig. \\
\hline $\begin{array}{l}\text { Kemampuan } \\
\begin{array}{c}\text { Pemahaman } \\
\text { Konsep }\end{array}\end{array}$ & $\begin{array}{c}\text { Pretest } \\
\text { Kontrol }\end{array}$ & 0,127 & 36 & 0,151 & 0,944 & 36 & 0,067 \\
\cline { 2 - 8 } & $\begin{array}{c}\text { Posttest } \\
\text { Kontrol }\end{array}$ & 0,138 & 36 & 0,079 & 0,954 & 36 & 0,143 \\
\hline
\end{tabular}

Dari tabel 1 yang diperoleh melalui melalui program SPSS For Windows Versi 25 didapat bahwa nilai probabilitas preetest kemampuan pemahaman konsep kelas kontrol (e-learning) sebesar 0,151 pada uji Kolmogrov-Smirnov dan 0,067 pada uji Shapiro-Wilk yang nilai keduanya lebih besar dari taraf signifikan 0,05 . Hal ini menunjukkan bahwa sampel yang diambil berdistribusi normal. Dan nilai probabilitas posttest kemampuan pemahaman konsep kelas kontrol (e-learning) sebesar 0,079 pada uji Kolmogrov-Smirnov dan 0,143 pada uji Shapiro-Wilk yang nilai keduanya lebih besar dari taraf signifikan 0,05 . Hal ini menunjukkan bahwa sampel yang diambil berdistribusi normal.

Tabel 2. Hasil Uji Normalitas Kemampuan Kelompok Eksperimen

(Blended Learning berbasis Quided Inquiry)

\begin{tabular}{cccccccc}
\hline \multicolumn{2}{c}{ Kelas } & \multicolumn{3}{c}{ Kolmogorov-Smirnov } & \multicolumn{3}{c}{ Shapiro-Wilk } \\
\cline { 2 - 8 } & & Statistic & df & Sig. & Statistic & df & Sig. \\
\hline $\begin{array}{c}\text { Kemampuan } \\
\text { Pemahaman } \\
\text { Konsep }\end{array}$ & $\begin{array}{c}\text { Pretest } \\
\text { Eksperimen }\end{array}$ & 0,119 & 35 & 0,200 & 0,958 & 35 & 0,194 \\
\cline { 2 - 8 } & $\begin{array}{c}\text { Posttest } \\
\text { Eksperimen }\end{array}$ & 0,131 & 35 & 0,139 & 0,951 & 35 & 0,124 \\
\hline
\end{tabular}

Dari tabel 2 yang diperoleh melalui melalui program SPSS For Windows Versi 25 didapat bahwa nilai probabilitas preetest kemampuan pemahaman konsep kelas eksperimen (blended learning berbasis quided inquiry) sebesar 0,200 pada uji Kolmogrov-Smirnov dan 0,194 pada uji Shapiro-Wilk yang nilai keduanya lebih besar dari taraf signifikan 0,05 . Hal ini menunjukkan bahwa sampel yang diambil 
berdistribusi normal. Dan nilai probabilitas posttest kemampuan pemahaman konsep kelas eksperimen (blended learning berbasis quided inquiry) sebesar 0,139 pada uji Kolmogrov-Smirnov dan 0,124 pada uji Shapiro-Wilk yang nilai keduanya lebih besar dari taraf signifikan 0,05. Hal ini menunjukkan bahwa sampel yang diambil berdistribusi normal.

Pada uji homogenitas jika data yang diperoleh $>0,05$ maka data tersebut dinyatakan homogen yang berarti kelompok data berasal dari populasi yang sama (homogen). Dan pada uji hipotesis jika data yang diperoleh $<0,05$ maka terdapat pengaruh pembelajaran blended learning berbasis quided inquiry terhadap kemampuan pemahaman konsep mahasiswa.

Tabel 3. Hasil Uji Homogenitas Kemampuan Pemahaman Konsep

\begin{tabular}{ccccc}
\hline Kelas & $\begin{array}{c}\text { Levene } \\
\text { Statistic }\end{array}$ & $\mathrm{df1}$ & $\mathrm{df2}$ & Sig. \\
\hline Kontrol & 0.589 & 1 & 70 & 0.445 \\
\hline Eksperimen & 0.006 & 1 & 68 & 0.941 \\
\hline
\end{tabular}

Dari hasil pengujian homogenitas melalui program SPSS For Windows Versi 25, diperoleh bahwa hasil data kelas kontrol 0,445>0,05 dan 0,941>0,05 pada kelas eksperimen. Hal ini menunjukkan bahwa data sampel yang digunakan berasal dari populasi yang memiliki varian yang sama (homogen).

Tabel 4. Hasil Uji Hipotesis Kemampuan Pemahaman Konsep

\begin{tabular}{cccccc}
\hline & Sum of Squares & df & Mean Squares & F & Sig. \\
\hline Between Groups & 18928.065 & 3 & 6309.355 & 152.395 & 0.000 \\
\hline
\end{tabular}

Dari hasil pengujian hipotesis dengan menggunakan one way ANOVA melalui program SPSS For Windows Versi 25, diperoleh bahwa hasil data $0,000<0,05$ pada nilai preetest dan posttest kelas kontrol dan kelas eksperimen. Hal ini menunjukkan bahwa pembelajaran blended learning berbasis quided inquiry berpengaruh terhadap kemampuan pemahaman konsep mahasiswa. Setelah pengujian hipotesis yang menunjukkan terdapat pengaruh pembelajaran blended learning berbasis quided inquiry sehingga dilanjutkan dengan uji N-Gain menurut Fitriatien (2017:50) yang menunjukkan terdapat perbedaan yang signifikan antara nilai kelompok kontrol dan kelompok eksperimen seperti pada tabel 5 berikut.

Tabel 5. Tabel Hasil Efektivitas N-Gain Persen Kelompok Kontrol dan Kelompok Eksperimen Kemampuan Penguasaan Konsep

\begin{tabular}{|c|c|c|c|c|c|}
\hline \multirow[t]{2}{*}{ Kelas } & \multirow{2}{*}{$\begin{array}{c}\text { Skor } \\
\text { Maksimum }\end{array}$} & \multirow{2}{*}{$\begin{array}{c}\text { Skor } \\
\text { Minimum }\end{array}$} & \multirow{2}{*}{$\begin{array}{l}\text { Standar } \\
\text { Deviasi }\end{array}$} & \multicolumn{2}{|c|}{ N-Gain } \\
\hline & & & & Nilai & Kriteria \\
\hline Kontrol & 71,43 & 16,67 & 16,16 & 40,5897 & Kurang Efektif \\
\hline Eksperimen & 100 & 28 & 19,10 & 68,7763 & Cukup Efektif \\
\hline
\end{tabular}

Berdasarkan hasil pengujian N-Gain Score diperoleh hasil bahwa nilai N-Gain pada kelompok kontrol sebesar 40.5897 atau 40,6\% termasuk dalam kategori "Kurang Efektif" dan nilai N-Gain pada kelompok eksperimen sebesar 68,7763 atau 68,8\% termasuk dalam kategori "Cukup Efektif". 


\section{Analisis Kemampuan Berpikir Kreatif}

Dari hasil tes angket yang diberikan pada mahasiswa untuk melihat kemampuan berpikir kreatif mahasiswa yang diberikan selanjutnya dilakukan menjumlahkan dan mengkonversi skor dalam bentuk presentase dan mengkategorikan kemampuan berpikir kreatif mahasiswa dalam tabel 6 .

Tabel 6. Interpretasi Kemampuan Berpikir Kreatif (Efendi, 2017)

\begin{tabular}{cc}
\hline Persentase Pencapaian & Kategori \\
\hline $81-100$ & Sangat Baik \\
\hline $61-80$ & Baik \\
\hline $41-60$ & Cukup \\
\hline $21-40$ & Kurang \\
\hline $0-20$ & Sangat Kurang \\
\hline
\end{tabular}

Hasil tes angket kemampuan berpikir kreatif mahasiswa setelah dilakukan penjumlahan dan pengkonversian ke dalam bentuk presentasi dapat dilihat pada tabel 7 .

Tabel 7. Hasil Ketercapaian Aspek Berpikir Kreatif Mahasiswa

\begin{tabular}{ccccc}
\hline Kelas Penelitian & \multicolumn{4}{c}{ Ketercapaian Aspek Berpikir Kreatif (\%) } \\
\hline Kelancaran & $\begin{array}{c}\text { Kelenturan } \\
\text { (fleksibility) }\end{array}$ & $\begin{array}{c}\text { Keaslian } \\
\text { (originality) }\end{array}$ & $\begin{array}{c}\text { Penguraian } \\
\text { (elaboration) }\end{array}$ \\
\hline Kontrol & 39 & 46 & 44 & 38 \\
\hline
\end{tabular}

Dari hasil analisis data penelitian kelas kontrol pada aspek kelancaran (fluency) dan aspek penguraian (elaboration) berturut-turut memperoleh persentase sebesar 39\% dan 38\% yang keduanya termasuk dalam kategori interpretasi kurang baik terhadap kemampuan berpikir kreatif mahasiswa. Sedangkan pada aspek kelenturan (fleksibility) dan aspek keaslian (originality) intepretasi kelas kontrol terhadap kemampuan berpikir kreatif termasuk dalam kategori cukup baik.

Hasil analisis data penelitian pada kelas eksperimen pada aspek kelancaran (fluency), aspek keaslian (originality), dan aspek penguraian (elaboration) termasuk dalam kategori baik dengan persentase berturut-turut sebesar $71 \%, 75 \%$, dan $75 \%$ terhadap kemampuan berpikir kreatif mahasiswa. Sedangkan pada aspek kelenturan (fleksibility) intepretasi kelas eksperimen terhadap kemampuan berpikir kreatif mahasiswa termasuk dalam kategori sangat baik dengan persentase $81 \%$.

\section{Analisis Tanggapan Mahasiswa}

Penilaian tanggapan mahasiswa terhadap pembelajaran blended learning berbasis quided inquiry diberikan tes berupa angket yang terdiri dari 8 indikator tanggapan. Hasil penilaian tanggapan mahasiswa dikonversi dalam bentuk persentase. 


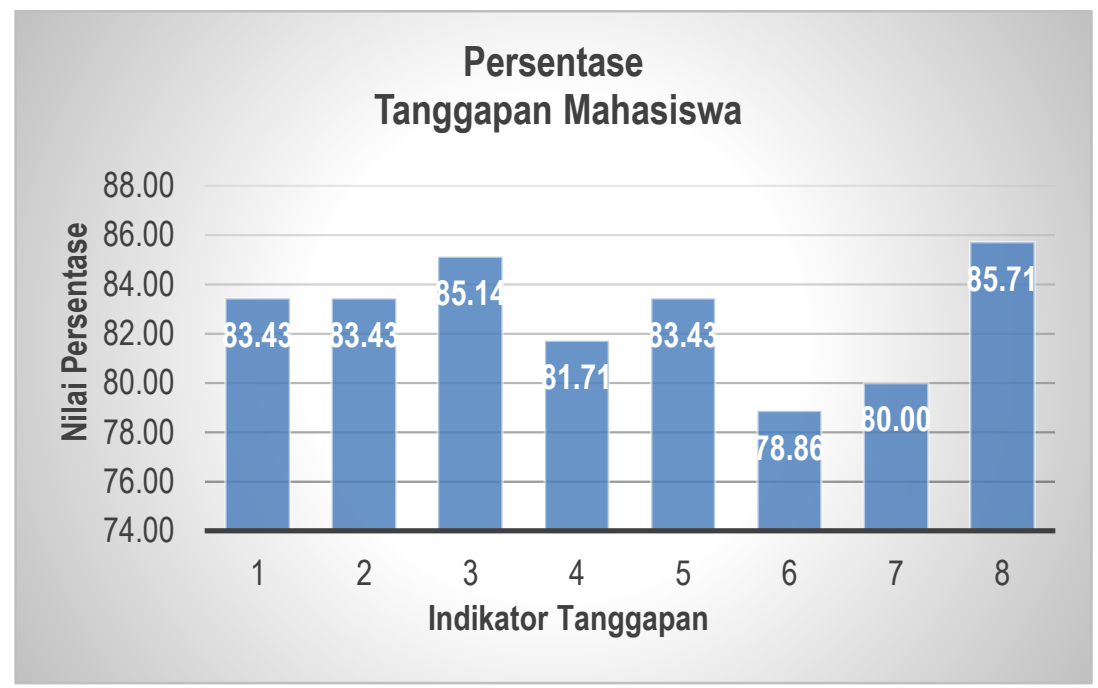

Gambar 1. Persentase Tanggapan Mahasiswa

Dari hasil analisis data yang telah dilakukan terhadap angket tanggapan mahasiswa, diperoleh bahwa terdapat dua aspek yang termasuk dalam kategori "Baik" yaitu indikator ke-6 dan ke-7. Hal ini disebabkan mahasiswa masih belum terbiasa menerima pembelajaran blended learning berbasis quided inquiry namun mahasiswa sangat senang dengan model pembelajaran yang diberikan karena dapat menambah motivasi belajar mahasiswa terlihat pada indikator ke-1 sampai indikator ke-5 dan indikator ke-8 yang termasuk dalam kategori "Sangat Baik" sehingga mahasiswa dapat lebih memahami pembelajaran anatomi fisiologi manusia.

Tabel 8. Tabel Hasil Tanggapan Mahasiswa

\begin{tabular}{|c|c|c|c|c|c|c|}
\hline Indikator & Aspek & Jumlah & $\%$ & Kategori & $\begin{array}{c}\% \\
\text { Rata- } \\
\text { Rata }\end{array}$ & Kategori \\
\hline 1 & $\begin{array}{l}\text { Saya tertarik terhadap pembelajaran } \\
\text { blended learning berbasis quided } \\
\text { inquiry pada mata kuliah Anatomi } \\
\text { Fisiologi }\end{array}$ & 146 & 83,43 & $\begin{array}{c}\text { Sangat } \\
\text { Baik }\end{array}$ & \multirow{7}{*}{82,71} & \multirow{7}{*}{$\begin{array}{c}\text { Sangat } \\
\text { Baik }\end{array}$} \\
\hline 2 & $\begin{array}{l}\text { Melakukan eksperimen dan observasi } \\
\text { mengenai struktur tubuh manusia } \\
\text { merupakan kegiatan yang } \\
\text { menyenangkan }\end{array}$ & 146 & 83,43 & $\begin{array}{c}\text { Sangat } \\
\text { Baik }\end{array}$ & & \\
\hline 3 & $\begin{array}{l}\text { Model pembelajaran blended learning } \\
\text { berbasis quided inquiry mendorong } \\
\text { saya untuk memecahkan masalah } \\
\text { secara berkelompok }\end{array}$ & 149 & 85,14 & $\begin{array}{c}\text { Sangat } \\
\text { Baik }\end{array}$ & & \\
\hline 4 & $\begin{array}{l}\text { Saya menjadi lebih memahami } \\
\text { keadaan struktur tubuh manusia dan } \\
\text { komponen yang ada di dalamnya }\end{array}$ & 143 & 81,71 & $\begin{array}{c}\text { Sangat } \\
\text { Baik }\end{array}$ & & \\
\hline 5 & $\begin{array}{l}\text { Saya menjadi mengerti struktur tubuh } \\
\text { manusia secara keseluruhan }\end{array}$ & 146 & 83,43 & $\begin{array}{c}\text { Sangat } \\
\text { Baik }\end{array}$ & & \\
\hline 6 & $\begin{array}{l}\text { Model pembelajaran blended learning } \\
\text { berbasis quided inquiry sangat mudah } \\
\text { dipahami dan dilaksanakan }\end{array}$ & 138 & 78,86 & Baik & & \\
\hline 7 & $\begin{array}{l}\text { Saya menjadi termotivasi untuk } \\
\text { memahami lebih dalam struktur } \\
\text { anatomi dan fisiologi dari tubuh } \\
\text { manusia }\end{array}$ & 140 & 80,00 & Baik & & \\
\hline
\end{tabular}


Dari hasil angket tanggapan yang diberikan kepada mahasiswa yang menerima pembelajaran dengan blended learning berbasis quided inquiry diperoleh data bahwa mahasiswa menyukai dan menyetujui pembelajaran diberikan dengan blended learning berbasis quided inquiry dengan kategori "Sangat Baik" dengan rata-rata hasil tanggapan $82,71 \%$.

Dari hasil analisis data yang didapat bahwa pembelajaran blended learning memiliki keunggulan dalam meningkatkan kemandirian mahasiswa dalam belajar dengan memanfaatkan internet untuk memperoleh informasi, selain itu, mahasiswa dapat mengakses materi pembelajaran kapanpun dan dimanapun tanpa batasan ruang dan waktu, sehingga proses pembelajaran dapat berjalan dengan optimal. Pada pertemuan tatap muka dilakukan pengayaan materi yang belum dapat dipahami mahasiswa, sehingga materi yang sudah dipelajari mahasiswa melalui internet dapat di kembangkan dan di sempurnakan pada pertemuan tatap muka. Pada pembelajaran blended learning mahasiswa juga bisa menemukan sendiri pemecahan dari suatu masalah melalui strategi pendekatan quided inquiry. Pada strategi ini, kegiatan pembelajaran dapat berlangsung dengan antusias karena mahasiswa dapat mencari semua informasi melalui internet dengan arahan dan bimbingan dosen sebagai fasilisator, sehingga tetap terjadi interaksi dalam proses pembelajaran tanpa batasan waktu.

Hal ini sejalan dengan penelitian Akhmalia, dkk (2018:1) bahwa pembelajaran blended learning berbasis LMS dengan model pembelajaran inkuiri pada materi fluida statis sangat efektif terhadap penguasaan konsep siswa. Nurusshobah, dkk (2018:1) menjelaskan bahwa siswa kelas eksperimen yang menggunakan model inkuiri terbimbing (quided inquiry) dapat diterapkan untuk meningkatkan penguasaan konsep siswa dan siswa memberikan respon positif terhadap pembelajaran model inkuiri terbimbing dengan kategori sangat setuju.

\section{SIMPULAN}

Berdasarkan hasil penelitian, ditemukan bahwa pembelajaran blended learning berbasis quided inquiry dapat meningkatkan kemampuan pemahaman konsep melalui hasil uji Anova diperoleh bahwa hasil data $0,000<0,05$ yang menunjukkan pembelajaran blended learning berbasis quided inquiry efektif terhadap penguasaan konsep mahasiswa dengan hasil N-Gain pada kelompok kontrol sebesar 40,6\% dengan kategori kurang efektif dan kelas eksperimen sebesar 68,8\% dengan kategori cukup efektif.

Pembelajaran blended learning berbasis quided inquiry efektif terhadap kemampuan berpikir kreatif mahasiswa pada aspek fluency sebesar $71 \%$, originality sebesar $75 \%$, dan elaboration sebesar $75 \%$ termasuk kategori baik, sedangkan pada aspek fleksibility termasuk ke dalam kategori sangat baik dengan persentase $81 \%$. Berdasarkan hasil angket tanggapan mahasiswa terhadap pembelajaran blended learning berbasis quided inquiry termasuk dalam kategori sangat baik dengan nilai rata-rata 82,71 .

\section{UCAPAN TERIMA KASIH}

Terimakasih kepada Sekolah Tinggi Farmasi Muhammadiyah Tangerang yang telah memeberikan fasilitas kepada peneliti untuk melakukan penelitian hingga penelitian ini selesai. Ungkapan terimakasih peneliti sampaikan kepada semua pihak yang telah membantu terlaksananya penelitian dan penyusunan artikel ini sehingga bisa terselesaikan. 


\section{RUJUKAN}

Aini, F. N. Q., \& Ismono, I. (2020). Implementation of Guided Inquiry Learning Model Based Blended Learning to Train Creative Thingking Skill of Eleventh Grade Students in The Factors that Affect of Chemical Equilibrium. Jurnal Pendidikan dan Pembelajaran Kimia, 9(3), 67-78.

Akhmalia, N.L., Maharta, N., \& Suana, W. (2018). Efektivitas Blended Learning Berbasis LMS dengan Model Pembelajaran Inkuiri Pada Materi Fluida Statis Terhadap Penguasaan Konsep. JIPFRI (Jurnal Inovasi Pendidikan Fisika dan Riset IImiah). 2(2); 56-64.

Bawaneh, S.S. (2011). The Effects Of Blended Learning Approach On Students' Performance: Evidence From A Computerized Accounting Course. Interdisciplinary Journal of Research in Business. Vol. 1, Issue. 4, April 2011. p.43-50

Borba, M.C., Askar, P., Engelbrecht, J., Gadanidis, G., Llinares, S., \& Aguilar, M.S. (2016). Blended Learning, E-Learning, an Mobile Learning in Mathematics Education. ZDM, 48(5); 589-610.

Czaplinski, I. \& Fielding A.L. (2020). Developing A Contextualised Blended Learning Framework To Enhancemedical Physics Student Learning And Engagement. Physica Medica. 72: 22-29.

Effendi, K. N., \& Farlina, E. (2017). Kemampuan Berpikir Kreatif Siswa SMP kelas VII dalam Penyelesaian Masalah Statistika. Jurnal Analisa, 3(2), 130-137.

Fatwa, M. W., Harjono, A., \& Jamaluddin, J. (2018). Pengaruh Model Pembelajaran Inkuiri Terbimbing Terhadap Keterampilan Proses Dan Penguasaan Konsep Sains Ditinjau Dari Pengetahuan Awal Peserta Didik. Jurnal Pendidikan Fisika dan Teknologi, 4(1), 121-130.

Fitriatien, S. R. (2017). Pengantar statistika untuk penelitian: Suatu kajian. Buana Pendidikan: Jurnal Fakultas Keguruan Dan IImu Pendidikan, 13(23), 47-53.

Frydenberg, M.E., \& Andone, D. (2011). Learning for 21st Century Skills. IEEE's International Conference on Information Society, London, 27-29 June 2011, 314-318.

Hermawanto., Kusairi, S., \& Wartono. (2013). Pengaruh Blended Learning Terhadap Penguasaan Konsep dan Penalaran Fisika Peserta Didik Kelas X. Jurnal Pendidikan Fisika Indonesia. 9(1); 67-76.

Husni, A., Juanda, E.A., \& Hamidah, I. (2010). Model Pembelajaran Kooperatif Berbantuan Web Pada Materi Fluida Statis Untuk Meningkatkan Pemahaman Konsep Siswa SMA. Prossiding Seminar Nasional Fisika 2010. p.451-458.

Indrawan, I.P., Gede, A.J.S \& I Komang, W.B.W. (2019). Kreativitas dan Motivasi Belajar Mahasiswa dalam Implementasi Blended Learning Berbasis Bali. International Journal of Natural Sciences and Engineering. 3(2): 70-78

Istiningsih, S. \& Hasbullah. (2015). Blended Learning: Trend Strategi Pembelajaran Masa Depan, Jurnal Elemen. 1(1): 49-56

Khomaidah, S., dan Koeswanti, H.D. (2020). Efektivitas Problem Based Learning dan Guided Inquiry Learning Terhadap Kemampuan Berpikir Kritis Siswa Sekolah Dasar. Jurnal Basicedu, 4(2) ; 371378.

Mayasari, F., Santoso, S., \& Octoria, D. (2016). Upaya Meningkatkan Kemandirian Belajar Siswa Melalui Penerapan Blended Learning Berbantuan Quipper School. Jurnal Tata Arta UNS, 2(3), 148-161.

Purwanto. (2013). Evaluasi Hasil Belajar. Yogyakarta: Pustaka Belajar.

Rahayu, E.S., \& Nuryata, I.M. (2010). Pembelajaran Masa Kini. Jakarta: Sekarmita Training publishing 
Sudarmanto, E., Kurniullah, A. Z., Revida, E., Ferinia, R., Butarbutar, M., Abdilah, L. A., .. \& Suyuthi, N. F. (2021). Desain Penelitian Bisnis: Pendekatan Kuantitatif. Yayasan Kita Menulis.

Sugiyono. (2010). Metode Penelitian Pendidikan, Pendidikan Kuantitatif, Kualitatif, dan R\&D. Bandung: Alfabeta.

Susilowati, E., \& Dewantara, D. (2021). Pengaruh Blended Learning Terhadap Keterampilan Berpikir Kritis Dan Ketrampilan Berpikir Kreatif. Prosiding Seminar Nasional Lingkungan Lahan Basah (Vol. 6, No. 1). p.1-5.

Trilling, B., \& Fadel, C. (2009). 21st Century Skills: Learning for Life in Our Times. New Jersey: John Wiley \& Sons.

Wardani, D.N., Anselmus, J.E.T., \& Agus, W. (2018). Daya Tarik Pembelajaran di Era 21 dengan Blended Learning. JKTP. 1(1): 13-18.

Winarsih, S., \& Priatmoko, S. (2019). Analisis Pemahaman Konsep Menggunakan Three-Tier Multiple Choice Test pada Pembelajaran Hidrolisis Berbantuan Metode Blended Learning Berbasis Inkuiri Terbimbing. Chemistry in Education, 8(2), 29-36.

Zinnuraini., Ulfa, M., \& Husnannisa, W. (2021). Penerapan Pembelajaran Blanded Learning Dalam Meningkatkan Kemampuan Berfikir Kreatif: Meta Analisis. Prosiding Penelitian Pendidikan dan Pengabdian 2021, 1(1), 413-426. 